\title{
Microbial and Physicochemical Qualities of Pasteurized Milk
}

\section{Woldemariam HW' ${ }^{*}$ and Asres $\mathrm{AM}^{2}$}

${ }^{1}$ Department of Food Process Engineering, College of Biological and Chemical Engineering, Addis Ababa Science and Technology University, Addis Ababa, Ethiopia ${ }^{2}$ Department of Food Technology and Food Process Engineering, Faculty of Chemical and Food Engineering, Bahir Dar Institute of Technology, Bahir Dar, Ethiopia

\begin{abstract}
A study was conducted to investigate the microbial and physicochemical qualities of pasteurized milk. The result of the microbial investigation indicated that Total Plate Counts were not significant $(p<0.05)$ between the samples but Coliform Counts $\left(3.1 \times 10^{6} \mathrm{cfu} / \mathrm{ml}\right)$ of sample $\mathrm{S}$ were significant. Physicochemical quality analysis revealed total solids and protein contents were not significant $(\mathrm{p}<0.05)$ for all pasteurized milk samples. On the contrary, fat contents of samples $\mathrm{M}(4.9 \%)$ and $\mathrm{S}(4.75 \%)$ were significant $(p<0.05)$, total ash $(0.6 \%)$ of sample $S$ was significant $(p<0.05)$ with the control $(0.8 \%)$ and lactose contents of samples $\mathrm{H}(2.07 \%)$ and S $(1.14 \%)$ were also significant $(p<0.05)$ with the control $(4.7 \%)$. Results of this study suggest that pasteurized milk samples tend to increased in microbial population is suggestive of unsanitary practices during processing and poor pasteurization efficiency. Besides, the variation in physicochemical compositions could be due to failure of regular standardization throughout the production period.
\end{abstract}

Keywords: Microbial quality; Pasteurized milk; Physico-chemical quality

\section{Introduction}

Milk is considered as nature's single most complete food [1]. Milk is a complex mixture of fat, protein, carbohydrates, minerals, vitamins, and other miscellaneous constituents dispersed in water, make it a complete diet [2]. The nature of milk and its chemical composition renders it one of the ideal culture media for microbial growth and multiplication [3]. The safety of dairy products with respect to foodborne diseases is a great concern around the world. This is especially true in developing countries where production of milk and various dairy products take place under rather unsanitary conditions and poor production practices [4]. Different heat and treatments are given to raw milk in order to remove pathogenic organisms, to increase the shelf life, to help subsequent processing, e.g. for warming before separation and homogenization or as an essential treatment before cheese making, yoghurt manufacture and production of evaporated and dried milk products [5].

Pasteurization, sterilization (in bottle) and UHT (ultra-hightemperature) treatment integrated with aseptic packing are two such treatments. Sterilization is the term applied to a heat treatment process which has a bactericidal effect greater than pasteurization. Although it does not result in sterility, it gives the processed milk a longer shelf life. Because of the long holding time at this elevated temperature, the product has a cooked flavour and a pronounced brown colour. Unlike sterilization, pasteurization is not intended to kill all pathogenic microorganisms in the food or liquid. Instead, pasteurization aims to reduce the number of viable pathogens so they are unlikely to cause disease. Physiochemical analysis is important tool to monitor the quality of milk and dairy products. Milk is an important source of all basic nutrients for mammals. Milk from various mammals are used for producing different dairy products including milk cream, butter, yogurt, ghee, sour milk, etc. [5,6]. Consumers always demands nutritionally enriched milk and dairy products $[7,8]$. According to World Health Organization (WHO) standards and other scientific works, quality milk contains $2.6 \%$ fat, $3.5 \%$ protein, $0.17 \%$ Titratable Acidity (TA), 7.71\% Solids-Not-Fat (SNF) and SG 1.030, total bacterial count $1.3 \times 10^{6} \mathrm{cfu} / \mathrm{ml}$. The $\mathrm{pH} 6.6$ ensures the milk freshness at boiling point $100^{\circ} \mathrm{C}$ to $117^{\circ} \mathrm{C}$ [9-13].

The other consumers concern is that there may be adulteration of milk with different substances especially with water. When adulteration is made there is question of safety. The milk may contain hazardous chemicals that may be added which cause health risk. The most common adulterant is water [9]. When the water is added, we are paying extra money that we should not pay in addition to this the added water quality may lead to health risk. The current processes for milk collection from many subsistence farmers are time-consuming, costly and prone to adulteration. Adulteration of milk can cause the deterioration of dairy products and to ensure milk quality requires the necessity and greater emphasis on regulatory aspects with advanced methods of analysis and monitoring milk production and processing, and the new product ideas such as genetically modified foods and the nutraceuticals have set new goals for quality assurance and food safety [14]. Fresh milk considered as a complete diet because it contains the essential nutrients as lactose, fat, protein, mineral and vitamins in balanced ratio rather than the other foods [9]. Recently, consumer's health concerns are developed to the milk properties i.e., SNF, TS, acidity, and bacterial count along with protein and fat content.

Pasteurized milk is not durable for long period due to poor time-temperature management, inappropriate storage conditions, adulteration and contamination. The other main problem of the producers is to examine routinely the efficiency of pasteurization and miss labeling. Therefore, the key objective of this study was to assess different pasteurized milks in terms of microbial and physicochemical quality due to the reason that there is supply of low quality milk due to high degree of milk adulteration and poor hygiene practice during milking, transporting, distributing, processing and serving.

*Corresponding author: Woldemariam HW, Department of Food Process Engineering, College of Biological and Chemical Engineering, Addis Ababa Science and Technology University, Addis Ababa, PO Box 16417, Ethiopia, Tel: +251-912038334; E-mail: henymarbdr@gmail.com

Received December 27, 2016; Accepted January 13, 2017; Published January 19, 2017

Citation: Woldemariam HW, Asres AM (2017) Microbial and Physicochemical Qualities of Pasteurized Milk. J Food Process Technol 8: 651. doi: 10.4172/21577110.1000651

Copyright: () 2017 Woldemariam HW, et al. This is an open-access article distributed under the terms of the Creative Commons Attribution License, which permits unrestricted use, distribution, and reproduction in any medium, provided the original author and source are credited. 
Citation: Woldemariam HW, Asres AM (2017) Microbial and Physicochemical Qualities of Pasteurized Milk. J Food Process Technol 8: 651. doi: 10.4172/2157-7110.1000651

\section{Materials and Methods}

\section{Sample collection}

Different brands of pasteurized milk samples were collected from Bahir Dar and Addis Ababa and stored in to a refrigerator at $4^{\circ} \mathrm{C}$ until analysis. The study was carried out from September 2014 to June 2015.

\section{Microbial analysis of pasteurized milk samples}

Microbial analyses were carried out to investigate the quality of pasteurized milks using standard methods [15-17]. One millilitre of pasteurized milk from each sample was homogenized in $9 \mathrm{~mL}$ of standard Maximum Recovery Diluent before undertaking the microbial analysis (Figure 1). Maximum Recovery Diluent and media prepared for each test (except Violet Red Bile Agar (VRBA) was autoclaved for $15 \mathrm{~min}$ at $121^{\circ} \mathrm{C}$ [17]. Media used were prepared according to the directions given by the manufacturers on the packaging materials.

The number $(\mathrm{N})$ of $\mathrm{cfu} / \mathrm{mL}$ of a sample is calculated according to the method described by Roberts and Greenwood [18]:

$$
N=\frac{C}{v\left(n_{1}+0.1 n_{2}\right) d}
$$

Where,

$\mathrm{C}$ is the sum of colonies on all plates counted.

$\mathrm{v}$ is the volume applied to each plate.

$\mathrm{n}_{1}$ is the number of plates counted at the first dilution.

$\mathrm{n}_{2}$ is the number of plates counted at the second dilution.

$\mathrm{d}$ is the dilution from which the first count was obtained.

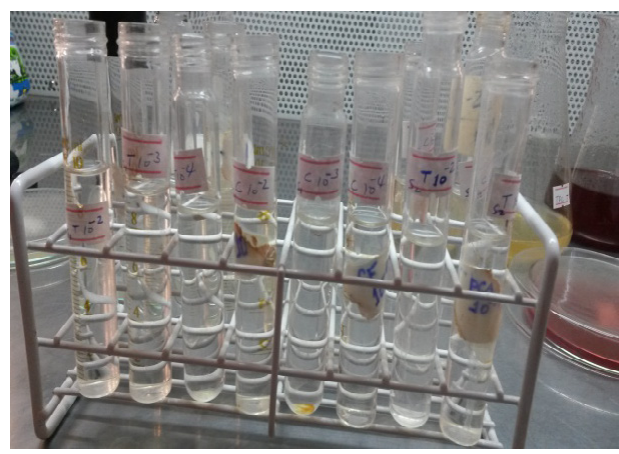

Figure 1: Preparation of dilutions.

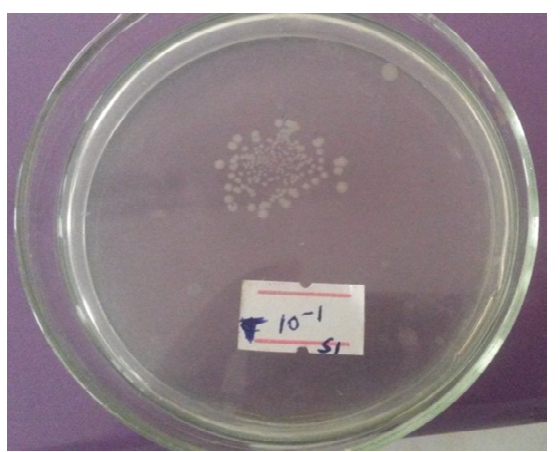

Figure 2: Total plate counts of pasteurized milk samples.

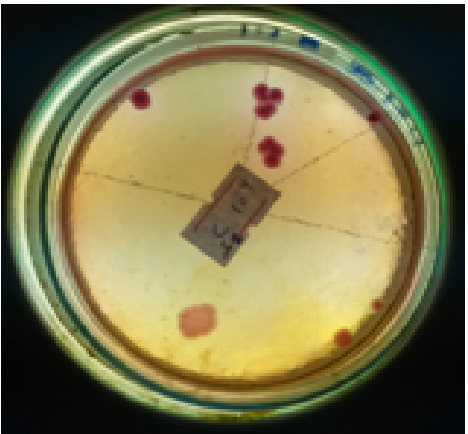

Figure 3: Coliform counts of pasteurized milk samples.

\section{Microbial counts}

The pasteurized milk samples were assessed for Total Plate Counts (TPC) and Coliform Counts (CC). Dilutions were selected so that total number of colonies on a plate was between 30 and 300 for TPC, while for CFC; dilutions were selected for plate counts between 15 and 150 [16,17].

\section{Total plate count (TPC)}

Homogenized pasteurized milk sample was serially diluted by adding $1 \mathrm{~mL}$ into $9 \mathrm{~mL}$ of Maximum Recovery Diluent, until a solution is obtained that is expected to give a plate count between 30-300. One millilitre of the sample from a chosen dilution was placed on the petri dish with pour plated molten plate count agar (10-15 ml) allowed to solidify for $15 \mathrm{~min}$ and incubated for 48 hours at $37^{\circ} \mathrm{C}$ (Figure 2). Finally, the counts were made using digital colony counter. The plate counts were calculated by multiplying the count on the dish by $10 \mathrm{n}$, in which $\mathrm{n}$ stands for the number of consecutive dilutions of the original sample [15-17].

\section{Coliform count (CC)}

One $\mathrm{ml}$ of milk sample serially diluted as 1:10 was transferred into sterile plates. Molten violet red bile agar $(15 \mathrm{ml})$ having temperature of $45^{\circ} \mathrm{C}$ was added to the milk sample, mixed thoroughly, and allowed to solidify for 5-10 minutes. The mixture was then overlaid with plating agar to inhibit surface colony formation and incubated at $37^{\circ} \mathrm{C}$ for 24 hours (Figure 3). Counts were made using colony counter [15-17].

\section{Physico-Chemical Analysis \\ Milk fat}

Gerber method was used to determine the milk fat content. Milk samples were kept at $37^{\circ} \mathrm{C}$ for 30 minutes in a water bath. Ten millilitres of concentrated sulphuric acid was pipetted into a butyrometer. Then, $11 \mathrm{ml}$ of milk was added using milk pipette into a butyrometer having the sulphuric acid, and then one millilitres of amyl alcohol was added. The butyrometer stopper was put on and the sample was shaken and inverted several times until all the milk was digested by the acid. Then, the butyrometer was placed in a water bath at $65^{\circ} \mathrm{C}$ for five minutes. The sample was placed in a Gerber centrifuge (Model: NOVA/3670$2631 /$, Germany) for four minutes at $1100 \mathrm{rpm}$. Finally, the sample was placed in to water bath for 5 minutes at $65^{\circ} \mathrm{C}$ and fat percentage was read from the butyrometer (Figure 4 ). The average of triplicate readings was computed and recorded $[15,16]$.

\section{Total solids}

To determine the total solids, five grams of milk sample was placed 
Citation: Woldemariam HW, Asres AM (2017) Microbial and Physicochemical Qualities of Pasteurized Milk. J Food Process Technol 8: 651. doi: 10.4172/2157-7110.1000651

Page 3 of 5

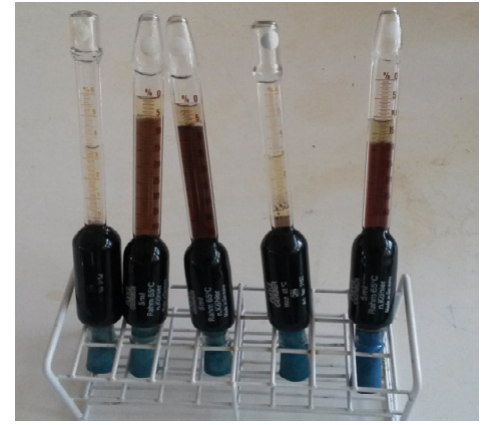

Figure 4: Fat readings of pasteurized milk samples.

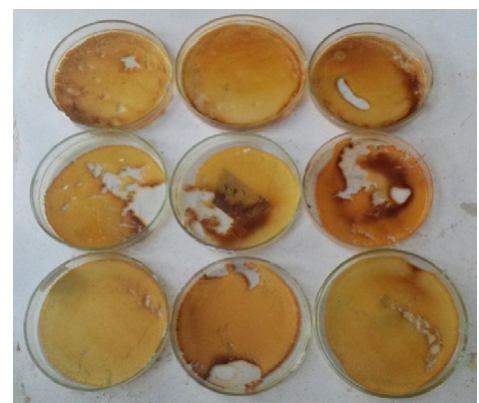

Figure 5: Total solids of pasteurized milk samples.

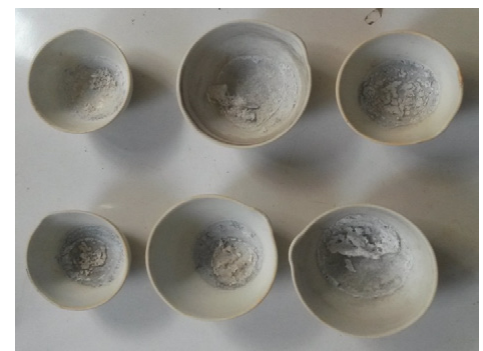

Figure 6: Ashe of pasteurized milks

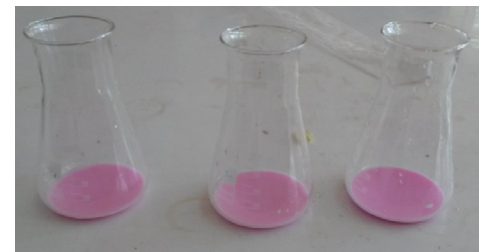

Figure 7: Total protein determination of pasteurized milks by titration method.

in a pre-weighed and dried triplicate of crucibles. The samples were kept at $102^{\circ} \mathrm{C}$ in a hot air oven (Model: DHG-9140, China) overnight. Then, the dried samples were taken out of the oven and placed in a desiccators (Figure 5). Then the dry sample was weighed and total solids were calculated using the following formula [19]:

$$
\text { Total Solids }=\left(\frac{\text { Crucible weight }+ \text { oven dry weight }- \text { Crucible weight }}{\text { Sample weight }}\right) \times 100
$$

\section{Total ash}

Total ash was determined gravimetrically by igniting the dried milk samples in a muffle furnace (Model: FSL 340-0100, UK) in which the temperature was slowly raised to $550^{\circ} \mathrm{C}$. The samples were ignited until carbon (black color) disappears or until the ash residue becomes white (Figure 6) and total ash was calculated using the following formula [16]:

$$
\text { Total ash }=\left(\frac{\text { Weight of residue }}{\text { Weight of sample }}\right) \times 100
$$

\section{Total protein}

Formaldehyde titration method was used to determine the total protein content. Ten $\mathrm{ml}$ of milk was added into a beaker. Then, 0.5 $\mathrm{ml}$ of 0.5 percent phenolphthalein indicator and $0.4 \mathrm{ml}$ of 0.4 percent Potassium Oxalate was added into the milk. Then, the sample was titrated with $0.1 \mathrm{~N}$ Sodium Hydroxide solution. The titration was continued until pink color becomes intense (Figure 7). Finally, the burette reading was recorded. The reading was multiplied by a factor 1.74 and total protein was calculated using the formula below [20].

Total protein $=$ Burette reading $\times 1.74$

\section{Solids- not -fat (SNF)}

The solids not fat (SNF \%) was determined with the equation below by subtracting the percent fat from total solids [20].

$$
S N F=(T S-f a t) \times 100
$$

\section{Lactose}

Percent lactose was determined by subtracting the fat, protein and total ash percentages from the percentage of the total solids [1].

Percent lactose $=$ Percent total solids $-(\%$ fat $+\%$ protein $+\%$ total ash $)$

\section{Data analysis}

Triplicate data collected for microbial and physicochemical qualities were subjected to one way of ANOVA at $\mathrm{p}<0.05$ using SAS version 9 [21].

\section{Results and Discussion}

The study was aimed to assess the microbial and physicochemical qualities of different brands of pasteurized milk samples. Accordingly, the samples were tested for Total Plate Counts (TPC), Coliform Counts (CC), fat, total solids, total ash, total protein, solids-not-fat (SNF) and lactose.

\section{Microbial analysis of milk samples}

Different brands of pasteurized milk samples were analyzed for TPC and CC and results are displayed in Table 1.

Results revealed that Total Plate Counts were not significant between the samples. However, one of the samples (S) is significant at $\mathrm{p}<0.05$ in terms of Coliform Counts (Table 1). Total plate count is the most accurate method for counting live microorganisms in raw milk and heat-treated milk [17]. Milk produced under hygienic conditions from healthy cows should not contain more than $5 \times 10^{4}$ bacteria per millilitre [22]. Therefore, the total bacterial counts of the collected samples were higher than acceptable standard, which could be associated with poor efficiency of pasteurization.

Coliform bacteria could contaminate milk from dung, bedding materials, polluted water used for cleaning, soil and inadequately cleaned milking utensils $[17,23]$. This could possibly expose the milk to high risk of contamination, which in turn increases the microbial count. Coliform count is especially associated with the level of hygiene 
Citation: Woldemariam HW, Asres AM (2017) Microbial and Physicochemical Qualities of Pasteurized Milk. J Food Process Technol 8: 651. doi: 10.4172/2157-7110.1000651

\begin{tabular}{|c|c|c|}
\hline & \multicolumn{2}{|c|}{ Microbial quality parameters } \\
\hline Samples & TPC (cfu/ml) & CC (cfu/ml) \\
\hline $\mathrm{M}$ & $2.6 \times 10^{6}$ & $<30$ \\
\hline $\mathrm{H}$ & $3.6 \times 10^{6}$ & $<30$ \\
\hline $\mathrm{S}$ & $2.1 \times 10^{6}$ & $3.1 \times 10^{6+*+}$ \\
\hline $\mathrm{R}$ & $<30$ & $<30$ \\
\hline
\end{tabular}

Comparisons significant at $p<0.05$ are indicated by ${ }^{* * *} M, H, S$ and $R$ are codes for different pasteurized milk samples.

Table 1: Microbial analysis result of milk samples.

\begin{tabular}{|c|c|c|c|c|c|c|}
\hline \multirow[b]{2}{*}{ Samples } & \multicolumn{6}{|c|}{ Physico-chemical quality parameters } \\
\hline & Fat $(\%)$ & $\begin{array}{c}\text { Total } \\
\text { Solids (\%) }\end{array}$ & $\begin{array}{c}\text { Total Ash } \\
\text { (\%) }\end{array}$ & $\begin{array}{c}\text { Total Protein } \\
(\%)\end{array}$ & $\begin{array}{l}\text { SNF } \\
(\%)\end{array}$ & $\begin{array}{c}\text { Lactose } \\
(\%)\end{array}$ \\
\hline M & $2.9^{* * *}$ & 9.8 & 0.63 & 3.42 & 2.27 & 2.85 \\
\hline $\mathrm{H}$ & 4.4 & 11.93 & 0.69 & 4.79 & 3.72 & $2.07^{\star \star \star}$ \\
\hline S & $4.75^{\star * *}$ & 10.04 & $0.6^{\star * *}$ & 4.0 & 4.16 & $1.14^{* * *}$ \\
\hline $\mathrm{R}$ & 3.25 & 11.05 & 0.66 & 4.35 & 2.59 & 2.79 \\
\hline Ctrl & 2.7 & 11.7 & $0.8^{* \star *}$ & 3.5 & 1.9 & $4.7^{* * *}$ \\
\hline
\end{tabular}

Comparisons significant at $\mathrm{p}<0.05$ are indicated by ${ }^{* * *}$. M, H, S, R and Ctrl are codes for different pasteurized milk samples.

Table 2: Physicochemical analysis result of milk samples.

during production and subsequent handling since they are mainly of faecal origin $[17,24]$. Coliforms do not survive pasteurization and their presence in the pasteurized milks indicates recontamination after pasteurization. If coliform count of any milk is higher than a certain level, say over ten coliform organisms per millilitre of pasteurized milk, it means the milk was produced under improper procedures [25]. The existence of coliform bacteria in high proportion is suggestive of unsanitary condition or practices during processing [16].

\section{Physicochemical analysis of milk samples}

The results of milk fat, total solids, total ash, total protein, solidsnot-fat (SNF) and lactose of pasteurized milk samples are presented in Table 2. The total solids and protein contents were found to be not significant at $\mathrm{p}<0.05$ for all types of pasteurized milk samples (Table 2). On the other hand, the fat content of pasteurized milk samples (M) and $(\mathrm{S})$ were significant at $\mathrm{p}<0.05$ with other samples and the control (label on the package by the manufacturer). Besides, the ash content of sample (S) is significant at $\mathrm{p}<0.05$ only with the control (Table 2 ).

Lactose contents of samples $(\mathrm{H})$ and $(\mathrm{S})$ are significantly different at $\mathrm{p}<0.05$ with the control. In addition, samples (M) and (S) are significant at $\mathrm{p}<0.05$ in terms of their lactose and solid-not-fat contents with each other (Table 2).

\section{Conclusion}

The milk samples under consideration failed to maintain the standard quality of milk both microbiologically and chemically. The presence of bacterial population in processed milk indicates defect in processing plants. The actual microbial counts indicated poor microbial quality of milk samples which might be due to poor pasteurization efficiency or recontamination. The chemical compositions of the milk analyzed were not similar with that of the control except total solids content. From the study, it is possible to conclude that the producers were not properly standardizing the milk components based on their standards and routinely examining the qualities of pasteurized milks immediately before the products are released in to the market. Thus, frequent inspection of pasteurized milks by responsible bodies is vital to check whether the products meet the minimum legal standards and should monitor the overall hygienic condition surrounding the production and handling of milk. Realistic standards for pasteurized milk need to be devised and appropriate training should be given to producers in hygienic handling of milk. It is recommended therefore, that adequate sanitary measures be observed at all stages of processing to consumption of the pasteurized milk to protect the milk from spoilage which eventually be posing a serious health risk to the consumers.

\section{Acknowledgement}

The authors gratefully acknowledge the School of Research and Graduate Studies of Bahir Dar Institute of Technology for financial support and the School of Chemical and Food Engineering for supporting with laboratory facilities for the study.

\section{References}

1. O'Mahoney F (1988) Rural dairy technology-experiences in Ethiopia. ILCA Manual No 4, Dairy Technology Unit ILCA, Addis Ababa, Ethiopia.

2. Haug A, Hostmark AT, Harstad OM (2007) Bovine milk in human nutrition: A review. Lipids in Health and Disease 6: 25.

3. Soomro AH, Arain MA, Khaskheli M, Bhuto B (2002) Isolation of $E$. coli from raw milk and milk products in relation to public health sold under market conditions at Tandonjam. Pakistan J Nutri 1: 150-152.

4. Zelalem Y, Faye B (2006) Handling and microbial quality of raw and pasteurized cow's milk and Irgo-fermented milk collected from different shops and producers in Central Highlands of Ethiopia. Eth J Anim Prod 6: 67-82.

5. Singh HS (1993) Heat induced interactions of proteins in milk. Protein and fat globule modifications. IDF seminar Special Issue 93:191.

6. Bylund G (1995) Dairy processing handbook. Tetrapak Processing Systems AB S 22186 Lund, Sweden

7. Akhtar S, Zahoor T, Hashmi M (2003) Physico-chemical changes in UHT treated and whole milk powder stored at ambient temperature. Pakistan $J$ Research Science 14: 68-82.

8. Manji B, Khakuda K (1988)The role of protein denaturation, extent of proteolysis and storage temperature on the mechanism of age-gelation in a model. J Dairy Science 71: 194-201.

9. Clare DA, Bang WS, Cartwright G, Drake MA, Coronel P, et al. (2005) Comparison of sensory microbiological, and biochemical parameters of microwave verses indirect UHT fluid skim milk during storage. J Dairy Science 88:4172- 4182.

10. Davies FL (1975) Heat resistance of bacillus species. Int J Dairy Technology 28: 69-72.

11. Wilson HK, Herreid EO, Whitney RM (1960) Ultracentrifugation Studies of milk heated to terilization temperatures. J Dairy Science 43: 165-174.

12. Westhoff DC, Dougherty SL (1981) Characterization of bacillus species isolated from spoiled ultrahigh temperature processed milk. J Dairy Science 64: 572- 577.

13. Ramsey JA, Swartzel KR (1984) Effect of UHT processing and storage conditions on rates of sedimentation and fat separation of aseptically packaged milk. J Food Science 49: 257-262.

14. Datta N, Elliot AJ, Perkin ML, Deeth HC (2002) UHT treatment of milk: comparison of direct and indirect methods of heating. Australian $\mathrm{J}$ Dairy Technology 57: 211-257.

15. Marth EH (1978) Standard methods for the examination of dairy products (14 edn). American Public Health Association Washington DC, USA.

16. Richardson $\mathrm{GH}$ (1985) Standard methods for the examination of dairy products (15 $5^{\text {th }}$ edn). American Public Health Association, Washington DC, USA.

17. Van Den Berg JCT (1988) Dairy technology in the tropic and subtropics. Center for Agricultural Publishing and Documentation (Pudoc). Wagneningen, The Netherlands.

18. Roberts D, Greenwood M (2003) Practical food microbiology (3rdedn).

19. O'Connor CB (1994) Rural dairy technology: ILCA Training manual. International Livestock Research Institute, Addis Ababa, Ethiopia 1:119.

20. Foley YJ, Buckley J, Murphy MF (1974) Commercial testing and product control in the dairy industry. University College Cork. 
Citation: Woldemariam HW, Asres AM (2017) Microbial and Physicochemical Qualities of Pasteurized Milk. J Food Process Technol 8: 651. doi: 10.4172/2157-7110.1000651

Page 5 of 5

21. Gomez KA, Gomez AA (1984) Statistical procedures for agricultural research. John Wiley and Sons Inc, New York.

22. O'Connor CB (1993) Traditional cheese making manual. ILCA (International livestock center for Africa) Addis Ababa, Ethiopia.

23. Kalogridou-Vassiliaduo D (1991) Mastitis-related pathogen in goat milk. Small Rum Res 4: 203-212.
24. Omore A, Arimi S, Kaugethe E, McDermoh J, Staal S (2001) Assessing and managing milk-born health risk for the benfit of consumers in Kenya. Smallholder Dairy (R and D) project (SDP), Nairobi, Kenya.

25. Walstra P, Geurts TJ, Omen A, Jellema D, Van Boekel MAJS (1999) Dairy technology principles of milk properties and processes. Marcel Dekker Inc, New York. 